University of Nebraska - Lincoln

DigitalCommons@University of Nebraska - Lincoln

6-1962

\title{
SIGNIFICANT DEVELOPMENTS IN EUROPEAN CORN BORER RESEARCH1,2
}

\author{
T. A. Brindley
}

F.F. Dicke

Follow this and additional works at: https://digitalcommons.unl.edu/usdaarsfacpub

This Article is brought to you for free and open access by the U.S. Department of Agriculture: Agricultural Research Service, Lincoln, Nebraska at DigitalCommons@University of Nebraska - Lincoln. It has been accepted for inclusion in Publications from USDA-ARS / UNL Faculty by an authorized administrator of DigitalCommons@University of Nebraska - Lincoln. 


\title{
SIGNIFICANT DEVELOPMENTS IN EUROPEAN CORN BORER RESEARCH ${ }^{1,2}$
}

\author{
By T. A. Brindley and F. F. Dicke \\ Agricultural Research Service, Corn Borer Investigations, \\ U. S. Department of Agriculture, Ankeny, Iowa, and \\ Iowa State University of Science and Technology, Ames, Iowa
}

Since its identification as an introduced pest in 1917, the European corn borer, Ostrinia nubilalis (Hübner), has been investigated under widely different environmental conditions. During the first decade, the research was directed largely toward studies on biology and the development of control measures that were cultural, biological, and mechanical in nature. The important initial objective was a delaying action to reduce populations in the infested areas, thereby impeding the spread to the central Corn Belt. Legislation was enacted making it compulsory for growers to practice stipulated population-reducing measures. The spread west and south and the economics of harvesting and cultural practices in the large corn-acreage areas resulted in a shift of research emphasis to insecticides, varietal resistance, and biological control.

The literature on the European corn borer is extensive. It is not possible in the space available to cite and discuss here the data presented in the large number of papers that have contributed to the overall knowledge resulting from research conducted by the many agencies involved.

\section{BIOLOGY}

The first positive identification of the European corn borer in the United States was reported by Vinal (148), who reared the species from sweet corn in the vicinity of Boston, Massachusetts. The taxonomic status, known world distribution, and economic status, particularly in Europe, were discussed by Vinal \& Caffrey (149). Since the original description by Hübner, the synonomy has undergone a series of changes [Caffrey \& Worthley (38)]. A great volume of literature appeared between 1917 and 1960 under the species name Pyrausta nubilalis (Hübner). In a revision, Marion (93) placed nubilalis in the genus Ostrinia. This change has been accepted and adopted in recent literature.

The early studies were concerned mainly with life history and biology on sweet corn an important crop in the Boston area. Vinal \& Caffrey (149) described the life stages and habits of the larvae and adults. Two generations annually and many host plants were observed. Delayed planting and disposal of infested crop residues by various means were recognized 1962.

${ }^{1}$ The survey of the literature pertaining to this review was concluded in June,

'Journal Paper No. J-4388 of the Iowa Agricultural and Home Economics Experiment Station, Ames, Iowa. Project No. 1193. 
as feasible methods for reducing the borer population. On the basis of methods practiced in Europe, an area-wide "cleanup" campaign was instituted in Massachusetts, and quarantines were established to prohibit movement of infested host material from infested to noninfested areas.

The possible source of entry into the United States was investigated by Smith (137), who concluded that the most probable carrier was broomcorn from Hungary or Italy between the years 1909 and 1914. Discontinuous pockets of infestation were discovered in New York, Ontario, Pennsylvania, and Ohio in a few years [Gibson \& McLaine (70); Poos (125)]. Although broomcorn imported from Europe was thought to be the original source of the St. Thomas, Ontario infestation, Spencer \& Crawford (138) suggested that the source in the Welland area of Ontario could have been from transported infested corn. Different points of infestation along main arteries of rail transportation from the East would support the point they made. That separate introductions recurred in the Great Lakes region was supported by observations indicating that only a single generation prevailed annually in this location, as opposed to the multiple generations in the Eastern States. Because of this difference, the Great Lakes region became known as the area of the single-generation strain, and the eastern region as the area of the multiple-generation strain.

Intensive studies on the biology and the relationship of the European corn borer to its environment have been carried on continuously in the United States, Canada, Europe, and the Orient [Arbuthnot (2); Babcock (4); Bartley \& Scott (11); Caffrey \& Worthley (38); Chiang et al. (45) ; Clark (47); Everett et al. (62); Huber et al. (80); Jarvis (86); Jones et al. (88); Pesho (123); Ritcher (131) ; Stirrett (140); Thompson \& Parker (144)].

In the early infestation period, populations and crop damage reached a peak between 1925 and 1927, particularly in Ontario. The spread westward and southward was gradual between 1927 and 1936. In subsequent years, the movement of the insect, both west and south, was rapid. It reached the Prairie Provinces of Canada in 1949, and spread to the Rocky Mountains and Gulf States of Mississippi, Alabama, and Georgia by 1950. An all-time peak in population, which prevailed over much of the central Corn Belt, occurred in 1949. The populations leading to this peak in this area were predominantly bivoltine. Bivoltinism was sharply reduced in 1950 , as was the overall population. The population recovered gradually in subsequent years, with bivoltinism reaching levels of 80 to 90 per cent toward the latter part of the 1950-60 decade [Beck (16) ; Bird \& Stewart (30) ; Jarvis (86); Stirrett (140); Vance (146); Worthley \& Caffrey (153); Wressel (154)]. A small partial second generation was observed in the Great Lakes area [Caffrey \& Worthley (38); Crawford \& Spencer (52)]. Fluctuations in annual populations in the New England area were discussed by Barber (9). He attributed declines in population to such unfavorable natural factors as low night temperatures, rains, and heavy 
winds. These conditions had an important effect on the population of a generation and sometimes resulted in a reduced summer pupation and consequently low population of moths of the second generation.

Little importance was attached to the small amount of bivoltinism observed in the Great Lakes area. Bottger \& Kent (35) reported a bivoltine tendency in southeastern Michigan. Likewise, Ficht (66) observed a partial second generation in northeastern Indiana and pointed out the potential of bivoltinism in parts of Indiana. On the basis of weather data from stations in the United States, in addition to information available on the effect of climate on the number of generations of the borer occurring in Asia and Europe, Arbuthnot (2) charted generation zones in the United States. He emphasized the presence of strains and the persistence of single or more-than-one generation strains in zones most favorable for their multiplication. In a study of strains of the species originating from Ohio, Michigan, New York, and Connecticut, Arbuthnot (1) concluded that the material from Connecticut represented a homozygous multigeneration strain. A homozygous single-generation strain was isolated from the Ohio material, but a pure multiple-generation strain selection was not achieved in four generations of line breeding, since diapausing larvae appeared in each generation. The genetic factors responsible for the singlegeneration habit were interpreted to persist as recessive characters.

Voltinism and the factors associated with diapause, which occurs only in the full-grown larva, have been investigated in a wide range of environmental conditions. Buligan (36) indicated continued breeding in the Philippines. However, Viado et al. (147) refer to the species in the Philippines as Pyrausta salentialis. In field studies in the United States, Canada, Europe, Asia, and Africa, the larva of Ostrinia mubilalis has shown a genetic mechanism that will permit varying degrees of diapause in seasonal generations. Many investigators have concluded that diapause is closely associated with climatic conditions. Smith (136) observed bivoltinism in Manitoba, but Hudon (82) did not find it in Quebec. Eden (61) found 5-, 50-, and 100-per cent diapausing larvae, respectively, in the three seasonal generations in Alabama, and Peters et al. (124) reported similar results in Missouri. Mutchmore \& Beckel (103), rearing larvae at $65^{\circ} \mathrm{F}$, found that diapause increased from 0 to 95 per cent as the photoperiod increased from 0 to 9.5 to $14 \mathrm{hr}$ of light per day. At $65^{\circ} \mathrm{F}$, the most effective time of exposure for inducing diapause was before the second day of the final larval instar. Exposure during any single instar but the last was not effective.

Beck \& Hanec (21) investigated diapause under controlled dietary, photoperiod, and temperature conditions. Three readily discernible characteristics were noted; namely, arrested gonadal development, failure to pupate shortly after cessation of larval feeding, and reduction of oxygen consumption in mature larvae. At rearing temperatures of 23 to $25^{\circ} \mathrm{C}$, the mean threshold photoperiod was $15.4 \mathrm{hr}$ of light per $24 \mathrm{hr}$. They did 
not detect a critical growth stage of the larvae for diapause determination. The importance of voltinism will be further emphasized in connection with biological and insecticidal control and host-plant resistance.

\section{HOST PLANTS}

The European corn borer has been found to attack many species of plants belonging to widely different families. Corn is recognized as the preferred host although, in certain European areas, preference has been shown for other plant species such as hemp, hops, and mugwort. Some host crops or plant species are not attractive for oviposition to moths of the first generation or conducive to larval survival. Potatoes are more likely to be infested by the first generation, whereas grain sorghum, cotton, and some of the vegetable crops are more susceptible to attack by the second or third generation when corn is becoming unattractive for oviposition. It has been demonstrated that the species can maintain itself for two or more generations on some common cornfield weeds. Many species of weeds present in cornfields become infested through migration of larvae in more advanced stages of development [Clark (47); Dicke (55); Hodgson (77); Huber et al. (80); Karpova (89); Nagy (104); Poos (125); Takeuchi (141)].

The high attraction to moths of the first generation to early planted, taller corn, for oviposition, and less larval survival on later planted crops soon led to recommendation for delayed planting. This practice was particularly adapted to infestations of a univoltine population and gained favor in the Great Lakes region [Huber et al. (80)]. However, as a bivoltine population became established, the later plantings and the latematurity corn generally carried the higher populations which were largely of second-generation origin. Another factor against delayed planting in some areas of the Corn Belt is loss of yield because of summer droughts and need of a full season to produce and harvest a maximum storable crop [Chiang \& Hodson (41); Everett et al. (62)].

A large number of publications have dealt with the various phases of the general biological relationships between the European corn borer and its host, most specifically on corn. A knowledge of these relationships plays an important part in the development and application of population-management procedures. Vinal \& Caffrey (149) described the feeding habits of the larvae on corn and other hosts. It is apparent that their descriptions were based mainly on the location of the larger larvae on or in plant parts. No difference in injury was found between sweet and field corn. Considerable importance was attached to tassel breakage and poor pollination, although these injuries were not experimentally demonstrated.

Stage of growth, with height or tassel emergence and silking as indices, is recognized as important in determining relative plant attractiveness for oviposition and survival of larvae. Early planted corn which is normally taller and more mature receives more eggs of the first generation on 
a per-plant basis, and supports higher larval populations. The growth stage of the corn at the time the larvae hatch is important in determining whether the primary establishment and survival of larvae occur either on the leaves or on structures of the inflorescences [Beard (15); Caffrey \& Worthley (38); Everly (64); Huber et al. (80); Patch (109); Turner \& Beard (145)]. Differences in varietal attraction to moths for oviposition have been recorded by Everly (63) and Turner \& Beard (145). A wide range of attraction in inbred lines, independent of height and maturity, and transmission of these factors to crosses, has been demonstrated.

Detailed studies on the feeding habits of the larvae during the morphological development of the plant have shown that there is a general pattern of larval establishment on different plant parts. Batchelder (12), working on insecticidal control with sweet corn varying in maturity and exposed to the first generation, gave the following succession of larval locations: interfoliar spaces, immature tassel, florets, ear shoots, leaf sheath, and ears. In field (dent) corn the general pattern of first-instar larval establishment for the first generation was shown by Dicke (57) and Huber (79) to be closely associated with moist areas on the rolled whorl leaves. These authors noted that as the leaves of the plants became exposed and the larvae advanced in development, the primary feeding point of thirdand fourth-instar larvae was connected with the sheath and midrib, whereas the primary stalk invasion was by the fifth-instar larvae. In a histological study of the points of feeding on whorl leaf tissue, Bell (27) found the young larvae establishing themselves on thin-walled, bulliform cellular tissue.

For the second generation, which is abroad when field corn is, to a large extent, in the flowering and ear-development stage, the primary points of establishment of first-instar larvae are at the ligule and behind the sheath on pollen accumulations and on the young ear shoots. In this stage of growth, when the leaves are "grown out" as in early planted early maturing sweet corn during the first generation period, the "whorl" leaf blades lose their significance in larval establishment and survival [Dicke (57)].

The general trend of survival of larvae on whorl-stage corn shows a high mortality during the first five days after hatching, and a relatively low mortality thereafter that extends to the full-grown larval stage. Pollenshedding corn is more desirable for survival of larvae, since the early mortality is much lower on this stage than on whorl-stage corn. Because of higher levels of survival resulting from a second-generation infestation, stalk breakage and ear dropping become important harvesting problems [Dicke (57); Patch $(110,113)$ ].

Beck \& Apple (19) in further studies, reported that temperature and photoperiod affected developmental patterns of population samples from Wisconsin, southern Minnesota, Iowa, southern Ontario, Massachusetts, Nebraska, northern Kansas, Pennsylvania, and southeastern Missouri. The 
incidence of diapause and rate of larval growth differed significantly among the several populations.

Yield losses have been investigated in several areas under infestations resulting from either the first or second generation or both. In conditions prevailing in much of the Corn Belt, an infestation of the first generation results in important yield losses. Patch et al. $(116,117)$ estimated this loss to occur at about a rate of 3 per cent per mature larva per plant. Everett et al. (62) reported similar results for Ohio and Minnesota tests, but somewhat higher losses per larva for Iowa tests.

Losses resulting from infestations of the second generation have generally occurred at a rate of less than 2 per cent on a per-larva per-plant basis. However, losses in late-planted or late-maturing corn have approximated losses due to larvae of the first generation [Chiang et al. (44); Everett et al. (62) ].

Yield losses in susceptible and resistant hybrids were investigated by Everett et al. (62), Hibbs et al. (76), and Penny \& Dicke (120). Yield of hybrids resistant to the first generation was substantially more than that of susceptible hybrids. Similar tests against infestation by the second generation showed smaller losses in the resistant hybrids but with less differential than for resistance to the first generation.

\section{POPULATION STATISTICS}

Extensive population surveys in the Great Lakes area provided data for a study of sampling methods by Meyers \& Patch (102). They emphasized that randomness in taking samples is essential for obtaining unbiased estimates and concluded that increasing the number of samples of phases involving successively larger unit areas had a greater effect on increasing the reliability of the final mean values than like increases in successively smaller units.

Beall (14), in a statistical study of the heterogeneity of corn borer populations in plots, found that among four frequency distributions one fitted Neyman Type B, two Neyman Type A, and one the negative binominal. A study of data on complete larval populations on a $1 / 3$-acre block showed that the distribution to describe the population seemed to be the Poisson binomial [McGuire et al. (99)]. When the information was incomplete and based on a restricted random sample, the appropriate distribution seemed to be the negative binomial for fields with high density and the Poisson binomial for fields of low density.

Bancroft \& Brindley (7) gave illustrations of the use of nested sampling designs for estimating the mean and variance of corn borer populations and presented observations on stratified sampling with nested sampling.

Methods for artificially initiating infestations and evaluating populations or injury have been developed particularly for varietal resistance, chemical control, and yield loss studies [Dicke (57); Guthrie et al. (71); Kwolek \& Brindley (91); Patch (111); Patch et al. (113)]. 


\section{CONTROL}

\section{Biological}

Parasites.-It was early realized that one of the factors contributing to the phenomenal increase of the European corn borer in the United States was the lack of its native parasites. Work on the parasites of this insect had been mainly taxonomic in nature prior to the introduction of the pest into the Western Hemisphere. Careful studies were initiated by the Bureau of Entomology and Plant Quarantine of the U. S. Department of Agriculture in 1919 [Cartwright (40) ; Clark (47) ; Jones \& Caffrey (87); Thompson \& Parker (144)]. As a result of these studies, 24 species of parasites were introduced into the United States; 22 were numerous enough to permit colonization and of these the following are known to have become established: Lydella grisescens Robineau-Desvoidy, Horogenes punctorius (Roman), Macrocentrus gifuensis Ashmead, Sympiesis viridula Thomson, Chelonus annulipes Wesmael, and Phaeogenes nigridens Wesmael [Baker et al. (5)]. These authors also present detailed information on importations, laboratory-rearing procedures, colonization, sampling methods, and field status of these parasites through 1940. The status of releases in several states in the Corn Belt of the United States has been reported in detail by Arbuthnot \& Wright (3); Blickenstaff et al. (31) ; Cory et al. (49); Rolston et al. (132). These authors generally agree that Lydella grisescens is the most widely established and effective exotic parasite of the corn borer in the United States. Parasitization as high as 75 per cent, for example, was recorded in DuPage County, Illinois, in 1949.

Some question persists as to the exotic status of Lydella grisescens [Decker (53)]. Decker found Masicera senilis (Meigen) to be the most valuable of all parasites of Papaipema nebris (Guénée). This parasite was not released in Iowa until 1944 [Blickenstaff (31)]. Detailed studies by Beck, reported by Baker et al. (5), found $M$. senilis reported by Decker (53) to be, in fact, Lydella nigrita (Townsend). In later surveys, York et al. (156) found P. nebris to be parasitized by Lydella grisescens and no specimens of $L$. nigrita were recovered. It seems significant that in 1931 the most numerous parasite of $P$. nebris was L. nigrita, yet in 1955 it was identified as L. grisescens.

Predators.-Many common insect predators have been listed by authors reporting on the biology of the corn borer, but few serious studies to evaluate the impact of predators on the population have been carried out. This lack may be due, as Chiang \& Holdaway (42) have pointed out, to the difficulty encountered in direct measurement of predators. Many predators devour their prey and go away from the area without leaving a clue to their identity. Indirect evaluation by counting predators present can lead to erroneous conclusions, since density of predators may not be proportional to the intensity of their attack. Chiang \& Holdaway (42) proposed an index of predation, based on the difference between 
populations on screened and unscreened corn plants, and found an index of predation of 0.252 .

Conrad (48) found, in a study based on the examination of fecula, that the spotted lady bird beetle, Coleomegilla maculata (DeGeer) fed upon 16.5 and 15.3 per cent of the eggs in two fields. McCoy (98) determinated that the four-spotted fungus beetle, Glischrochilus quadrisignatus quadrisignatus (Say), reduced the population of borers 17 per cent through direct or indirect attack.

Studies on the value of birds as predators of the corn borer have been limited, but those that have been reported indicated that birds were playing an important part in the reduction of hibernating borers [Baker et al. (5) ; Barber (8) ; Caffrey \& Worthley (38) ]. The impact of predators on corn borer populations would be a fruitful study in corn borer population dynamics.

Pathogens.-The early work on the diseases of the European corn borer is adequately and concisely summarized by Steinhaus (139). In discussing the early experiments he states, "If we are to judge from the published accounts of these investigators, certain bacteria are among the most effective agents known for controlling the corn borer. For some reason, which the writer has never been able to ascertain with certainty, these successful efforts ceased shortly after 1930, and one is left in the dark as to why the bacterial method of control did not blossom into general use." The most successful pathogens isolated by these early workers were the bacterium Bacillus thuringiensis Berliner and the fungi Beauveria bassiana (Balsamo) Vuillemin and Metarrhizium anisopliae (Metchnikoff) Sorokin. Metalnikov \& Chorine (100) reported that B. thuringiensis applied as an aqueous suspension reduced the populations on manually infected plants from 50 borers per plant to 1.3 borers per plant. Wallengren \& Johansson (152) concluded that $M$. anisopliae was the most potent pathogen of the corn borer and that this fungus caused a death rate of 100 per cent. Bartlett \& Lefebvre (10) tried with inconclusive results to establish the fungus $B$. bassiana in nature.

A revival of interest in the control of insects by disease organisms was stimulated by the appearance of insects resistant to chemical insecticides and by an increasing awareness of the hazards of insecticide residues. McConnell \& Cutkomp (97) carried on extensive laboratory tests with $B$. thuringiensis and demonstrated that mortality increased as the spore count increased. Field tests, however, were inconclusive and McConnel \& Cutkomp indicated that this bacterium did not constitute a practical means of control. In field tests conducted in Iowa [York (155)], Beauveria bassiana caused reductions of 79 to 91 per cent on first-brood larvae, but was ineffective against the second-brood larvae. Revelo (130) reported 87.5 per cent control with three applications of a laboratory-cultured inoculum. Results of tests conducted in Canada [Hudon (83)] indicated that the susceptibility of the corn borer to B. thuringiensis was rather low and inconsistent, and that a relatively high dosage was required to give a satisfactory kill. 
The variable results with these pathogens, although discouraging, indicate that additional work on formulations and dosages could lead to satisfactory control of this insect with microbial agents.

The European corn borer also has been reported to be infected by two species of Microsporidia. Kotlan (90) found a protozoan infection in larvae collected in Hungary in 1927, and proposed the name Nosema pyraustae for the causative organism. Paillot (105) collected larvae in France which were infected with Microsporidia, which he named Perezia pyraustae. Steinhaus (139) suggested that $N$. pyraustae and $P$. pyraustae were the same species. Zimmack et al. (157) demonstrated that corn borer moths infected with this protozoan parasite laid fewer eggs, were shorter lived, and their progeny survived at a much lower level than did those from uninfected moths. This work suggests that $P$. pyraustae may be intimately associated with poor survival and resulting population fluctuations of this species. Raun (127) and Raun, York \& Brooks (128) developed means of determining infection rates and methods for eliminating microsporidial infections in laboratory cultures. It should now be possible to evaluate the role that this parasite plays in the population fluctuations of this insect. This parasite has not been grown outside of its host so it has not been used as a microbial agent. Much has otherwise been accomplished by workers with microbial agents, but much more remains to be done before these natural enemies can be used effectively to control the insect.

\section{Chemical}

The rapidity of the spread of the corn borer and the severity of its attack prompted extensive investigations of the chemical control of the pest in all infested areas. Extensive tests involving arsenicals, fluosilicates, and nicotine dusts were initiated more than 35 years ago [Worthley \& Caffrey (153)]. These applications were generally ineffective in protecting growing corn from injury. Factors contributing to this situation were the lack of satisfactory application equipment and of effective insecticide formulations, the nature of the feeding habits of the larvae, and the extended oviposition period of the pest.

Investigations carried out by Batchelder et al. (13) established that sprays applied to the whorl leaves of the corn plant during the period in which eggs of the corn borer were hatching, would reduce infestations and that certain forms of fixed nicotine applied at this time would give a degree of control consistent with commercial requirements. A schedule involving four applications, starting when hatching was first observed, was found to produce the most effective control. This schedule was followed by most workers for many years.

Derris was found to be effective when applied in the four-treatment schedule [Baker \& Questel (6)]. It was more effective in spray form than as a dust. Four applications of four pounds per acre of ground derris containing 4 per cent rotenone reduced borer populations 91.9 per cent. Ryanex, an insecticide of plant origin, prepared from Ryania speciosa Vahl. was tested in 1943 and 1944 [Pepper \& Carruth (121)]. A 50 per 
cent dust applied at 40 to 50 pounds per acre on a four-treatment schedule reduced borer populations 87 to 94 per cent. The control accomplished was outstandingly better on the average than control accomplished with other insecticides. This material gained some acceptance, especially among corn canners and market-garden growers; but it failed to attain general commercial acceptance because it proved to be difficult to apply as a spray formulation.

DDT was first tested against the corn borer in the laboratory in 1944. [Questel (126)]. The first evaluations showed this insecticide to be as effective as rotenone in spray formulations. Research data accumulated rapidly following this initial work. Authors differed on the formulations, rates, concentrations, and methods of application; but the data generally indicated that, with the proper timing of a four-treatment schedule, better than 90 per cent borer control could be accomplished.

Insecticide applications for corn borer control prior to 1947 had been limited to sweet corn, whereas the interests of seed corn and field corn growers had been neglected. The interests of these groups differ. Sweet corn producers strive for 100 per cent borer-free ears, whereas the seed producer and field-corn grower seek protection against stalk breakage, dropped ears, and improved quality at a minimum cost. Improved methods of timing and the effectiveness of DDT enabled Bigger et al. (28) to demonstrate the feasibility of controlling the corn borer on field corn.

Corn borer control on these crops was also improved and simplified by the development of granular formulations of insecticides and machines to apply them [Cox et al. (51)]. The corn plant and the feeding habits of the borer are peculiarly adapted to this type of control. The leaves of the corn plant form a natural trough that directs the granules deep into the whorl or the leaf axils of the corn plant where the newly hatched borers feed. This type of control has largely superseded all other methods on field corn.

Since the stover and cannery waste from corn are important as feed to livestock, residues resulting from insecticide applications to corn were of concern. Decker et al. (54) were among the first to study this problem. They pointed out that DDT weathers rather rapidly immediately after application and more slowly thereafter.

lem in great detail and arrived at similar conclusions. All insecticides recommended for corn borer control have been studied in similar fashion with the result that these insecticides, if used as recommended, can be applied without contamination of food or forage. The recommendations resulting from the accumulated research with insecticides have been effectively summarized by entomologists in the central Corn Belt of the United States (85).

With the acceptance of DDT as an insecticide to control the corn borer, it soon became evident that the most critical aspect of chemical control was proper timing. Various investigators have attempted to find foolproof means of determining the proper time to obtain the degree of control acceptable for the end use of the corn being grown, with a mini- 
mum number of applications. The following criteria have been suggested or recommended by different workers: (a) 1100 borer-degree days; (b) tassel-bud ratio of $30: 50$; (c) corn plant extended height of 35 inches; (d) 50 to 100 accumulated egg masses per 100 plants; (e) 87 per cent moth emergence; $(f) 75$ per cent of the plants with leaf-feeding damage; and $(g)$ first egg hatching. Each criterion has been used with some success, but also has had its limitations. These procedures were evaluated in a five-year study on field corn and discussed by Cox \& Brindley (50), and these authors concluded that as a single criterion of determining when to treat, the one based on 75 per cent leaf feeding was the simplest and most rapid, and as suitable as any of the other criteria.

\section{Varietal Resistance}

At the time the European corn borer was discovered in the United States and for some 15 years thereafter, only open-pollinated varieties were being grown. Although varieties of both field (dent) and sweet corn were tested and significant differences in infestation were apparent, such differences resulted primarily from differential oviposition and larval survival on variable growth stages within and between varieties. There is good evidence that some European varieties possess substantial resistance to first-generation attack. Roubaud (133) reported this type of resistance for the variety 'Dent de cheval,' and Horber (78) for the varieties 'Nostrano dell'isola' and 'Marano.' The development of many inbred lines of corn and commercial hybrids greatly stimulated search for resistant lines that might be utilized directly in hybrid combinations or for breeding germ plasm. The term resistance, as used in this review, refers to antibiosis as defined by Painter (106). Tolerance most commonly refers to standing and ear-holding qualities. Several facets of host-plant resistance were investigated as sources of resistance became available, particularly inheritance, breeding, and testing methods, and the nature of resistance or tolerance.

The first systematic breeding to develop resistant inbred lines in which 'Maize Amargo' was used as a source, was reported by Marston (94) and Marston \& Dibble (95). 'Maize Amargo' was crossed with Michigan varieties and selections were selfed in subsequent generations.

When the frequency of plant infestation in the $F_{1}$ and $F_{2}$ generations was considered, it was concluded that resistance was recessive and susceptibility dominant. The frequency of plant infestation in $F_{3}$ families indicated a 3:1 Mendelian ratio and a recessive resistance character. Tests of $\mathrm{F}_{4}$ selections showed a higher level of resistance than the parent $\mathrm{F}_{3}$ generation, an indication of continued segregation. Resistant lines of sweet corn were extracted from crosses of 'Maize Amargo' $X$ sweet corn varieties by Marston \& Mahoney (96).

Extensive cooperative programs were developed during the period $1930-40$ by the U. S. Department of Agriculture and many state experiment stations. Large numbers of inbred lines and crosses of both field and sweet corn were tested. In these tests, an infestation of the first or early 
summer generation was simulated. During this decade the open-pollinated varieties were rapidly replaced by hybrids which were usually crosses between two single crosses, commonly called double crosses. Reports on these research activities were made by Meyers et al. (101), Patch (108), Patch et al. (112), Patch \& Everly $(114,115)$, and Schlosberg \& Baker (134). Inbred lines with substantial resistance to larvel survival were found in small numbers. This resistance expressed itself in a high mortality of larvae during the first few days after egg hatch. The prepotency of transmitting resistance to crosses was investigated simultaneously and it was determined that heritable qualities were involved. There was a tendency for the component inbred lines in hybrids to be susceptible, but a high percentage of inbred lines tested were intermediate in resistance. Tests of hybrid combinations indicated that multiple factors were involved in resistance. Several lines with substantial resistance were agronomically acceptable in hybrid combinations. Hybrids with improved resistance and tolerance rapidly replaced open pollinated varieties. Prominent among inbred lines with improved resistance or tolerance were L317, R4, Oh40B, Oh07, Oh51, P8, K230, K226, MS285, Wis.CC5, and Hy. Some of the more agronomically desirable inbreds in commercial hybrids, particularly WF9, Tr, A, I153, CI.187-2, I11.90, A334, A375, Wis.CC2, Wis.CC6, and Wis.CC7, were susceptible. Open-pollinated varieties were the direct source material for most of the inbred lines developed from 1930 to 1940.

The rapid buildup in a two-generation population after 1940 and high incidence of stalk breakage and ear dropping, resulting from the infestation of the second generation, stimulated emphasis on breeding for greater tolerance. With different sources of resistance available, special crosses and synthetic varieties (composites of selected inbred lines) largely replaced breeding in open-pollinated varieties. Several types of resistance were recognized which were expressed in differential larval feeding on the leaf blade, leaf sheath, ear parts, and in the stalk. As a result of different modes of feeding by the larvae of the first and second generation, it was found that leaf-feeding resistance during the first generation was not significantly correlated with that of the second generation. Some inbred lines showing resistance to leaf feeding were highly susceptible to the second generation. Reports on various facets of breeding for resistance and tolerance to both the first and second generation were made by Burditt \& Holdaway (37), Chiang \& Holdaway (43), Dicke (56, 57), Dicke \& Guthrie (58), Dicke et al. (59), Dicke \& Penny (60), Everly (63), Guthrie et al. (71), Guthrie \& Stringfield (72, 73), Horber (78), Patch et al. (113), and Thomas et al. (143).

Studies to determine the number and location of genes or genetic factors on chromosomes have been made by several investigators. Ibrahim (84), using chromosomal interchanges, concluded that leaf-feeding resistance factors differentiating the inbred line A411 from the susceptible line A344 are associated with one gene on the long arm of chromosome 3 , one gene on the long arm of chromosome 4, and probably another on the long 
arm of chromosome 5. Tests of chromosomal interchange lines also indicated resistance factors other than those carried by A411. Working with first generation leaf feeding resistance in $F_{3}$ and backcross progenies of susceptible $X$ resistant $($ M14 $\times$ MS1), Ibrahim determined that segregation of genes at three or more loci was indicated. Similar tests with the susceptible $\times$ resistant cross $(B 14 \times N 32)$, indicated one or two gene pairs for resistance [Penny \& Dicke (118)].

In two susceptible $\times$ resistant crosses, $\mathrm{M} 14 \times \mathrm{gl}_{7} \mathrm{v}_{17}$ and WF9 $\times \mathrm{gy}_{7} \mathbf{v}_{17}$ estimates in $\mathrm{F}_{2}$ and backcross progenies showed that resistance differences were conditioned by segregation of genes at a single locus. The resistance gene was linked with the $\mathrm{gl}_{7} \mathrm{v}_{17}$ genes of the resistant parent with cross-over frequencies of 31 to 37 per cent [Penny \& Dicke (119)].

Fleming et al. (69) concluded from inheritance studies that relatively few major genes control resistance to leaf feeding and overall plant damage. Segregation was explained on the basis of two pairs of major genes, or equivalents, for overall damage. Backcrossing was suggested as a method of adding resistance to otherwise desirable inbred lines. Their results indicated that hybrid vigor may influence the amount of resistance.

The nature of host-plant resistance and nutritional facets have been under investigation over a period of years. Growth responses of larvae reared on different plant parts of single crosses $A \times \operatorname{Tr}$ (susceptible) and $\mathrm{R} 4 \times \mathrm{Hy}$ (resistant) were studied by Bottger (32). Leaves of $\mathrm{A} \times \mathrm{Tr}$ were more satisfactory for the growth of larvae than $\mathrm{R} 4 \times \mathrm{Hy}$. Sweet corn kernels satisfied the nutritive requirements better than any other material tested. Comparatively high survival was obtained on green beans, peas, and lettuce.

The sugar and protein content of leaves and internodes of corn plants and their effect on larval establishment, growth, and survival were reported on by Bottger (34). Leaves were relatively high in protein. Larvae reared on them showed high survival but low weight. Internodes were high in sugar and low in protein and showed low survival of larvae but relatively high weight. Detrimental effects were observed when reducing sugar was deficient, even in the presence of other sugars.

Mortality of newly hatched larvae was higher and development slower on $(\mathrm{R} 4 \times \mathrm{Hy})$ leaves than on susceptible $(\mathrm{WF} 9 \times 187)$ [Beck \& Lilly (22)]. Supplements of glucose in young plants improved survival and growth of young larvae fed on these plants.

Formulations of synthetic media to approximate the chemical composition of corn were tested for growth response of larvae by Bottger (33). Casein was found to be superior to zein as a source of protein, and peptone stimulated feeding and growth of larvae. A 2:1 ratio of glucose to sucrose satisfied the carbohydrate requirements. A nutritional value of vitamins $\mathrm{A}, \mathrm{B}$, and $\mathrm{E}$ was indicated. Rearings were successful through all stages.

An improved diet suspended in agar was developed by Beck et al. (23). An important requirement for optimum growth of larvae designated as "corn leaf factor," was found in lyophilized corn leaves. A mixture of ten B vitamins was not adequate in replacing brewer's yeast, and choline was an essential additive. To control contamination of the media, methyl 
parahydroxybenzoate (Nipagin $\mathrm{M}$ ) and $n$-butylparahydroxybenzoate (Butoben) were used. Aseptic and more precise rearing methods with artificial media were developed by Beck \& Stauffer (26). A great deal of research by Stanley D. Beck and his associates of the University of Wisconsin, who used these techniques, was centered around identifying the chemical nature of resistance and the nutritional facets associated with it. By their incorporation of substances fractionated from corn plants in aseptic media, they obtained growth-inhibiting reactions in bioassay. They isolated three fractions which were detected to be biologically active in reducing the rate of larval growth. These substances were designated resistant factors $\mathrm{A}, \mathrm{B}$, and $\mathrm{C}$ ( $\mathrm{RFA}, \mathrm{RFB}$, and $\mathrm{RFC}$ ). RFA and RFC were determined to be closely related substances and of most importance in inhibiting growth of larvae. Substance RFA was isolated in pure crystalline form and characterized as 6-methoxybenzoxazolinone. Laboratory synthesis was accomplished and a quantitative method was developedi for measuring its concentration in preparations. Other investigators, particularly in Finland, characterized 6-methoxybenzoxazolinone at about the same time in connection with disease resistance [Beck $(17,18)$; Beck \& Hanec (20); Beck \& Smissman (24, 25); Loomis et al. (92); Smissman et al. (135)]. The role of 6-methoxybenzoxazolinone and benzoxazolinone have been investigated in wheat, rye, and corn for their inhibitory effects on disease pathogens by Virtanen (150). He found that a precursor glucoside was originally present in plants and that the formation of benzoxa, zolinone and 6-methoxybenzoxazolinone appeared to result from a complex enzymatic action in the crushed plant material. The precursor gluco-1 sides did not show an inhibitory effect on pathogens but the aglucones formed showed antifungal activity. The possibility that RFA might be produced in the intestinal tract of the larvae was suggested.

In tests with inbred lines and commercial and experimental hybrids, Huber \& Stringfield (81) showed a significant positive correlation between resistance to the European corn borer and the corn leaf aphid, Rhopalosiphum maidis (Fitch). Guthrie \& Walter (74) in a five-year study of inbred lines of sweet corn developed for resistance to the corn earworm, Heliothis zea (Boddie), found that resistance to both insects occurred in some lines but was not consistently correlated.

Sorghum is seldom infested by the European corn borer in the vegetative or whorl stage of growth. In years of high populations, sorghum in the blossoming stage is attractive to second-generation moths. The young larvae primarily feed on the florets and developing grain, and later stages invade the stem mainly in the peduncle area. Tests of a series of varieties and hybrids representing a wide range of germ plasm have shown that, in general, Milo types are susceptible and Kafir types resistant to peduncle invasion, whereas crosses of these types range intermediate in resistance [Hodgson (77) ; Painter \& Weibel (107); unpublished data, U. S. Department of Agriculture and Iowa State University, Department of Science and Technology].

The association between European corn borer infestation and stalk, 
shank, and ear rots was studied by Christensen \& Schneider (46). Species of Fusarium were the most common pathogens isolated from infested shanks, stalks, and ears. In their analysis, the feeding activities and movement of larvae on the plant resulted in entry points for fungi and provided a favorable medium for increase of invading organisms, thereby making the tissues more subject to attack. Pepper \& Haeusler (122) observed that smut was reduced in early sweet corn when insecticides were applied for corn borer control.

\section{CULTURAL PRACTICES}

Reduction of the population by means of cultural practices and mechanical devices received a great deal of attention in the period 1920 to 1930. The general practice in the Eastern States and Great Lakes area of harvesting the corn crop by cutting and ensiling, or shocking and husking later, thus disposing of the infested stover by feeding to livestock, encouraged research on clean-surface culture. It was demonstrated that a high percentage of larvae perished under clean-plowing practices, ensiling, shredding stover, and stalk disposal in feed lots.

Implements were improved and devices were developed that were designed to eliminate as much of the population as possible between maturity of the crop and the time of soil preparation the following spring [Caffrey \& Worthley (39); Huber et al. (80); Reed et al. (129); Worthley \& Caffrey (153)].

To a large extent this population-reduction method of control lost its practical application as the insect established itself in the central Corn Belt. Growers employing the prevailing practices in this region leave most of the corn debris on the surface when the corn is followed by smallgrain crops. However, present-day cultural and mechanical harvesting practices are responsible for high rates of larval mortality. Bigger \& Petty (29), in a 10-year study, found about 95 per cent reduction of population through mechanical picking, pasturing stalk fields, and spring seedbed preparation.

\section{Light TRAPS}

Light traps, of various types and with different light sources, to attract moths, have commonly been used to obtain information on seasonal abundance. Electrocutor types have been investigated for possible effects of reducing infestations. Hervey \& Palm (75), using Mazda bulbs, were not able to show population reduction. Ficht \& Heinton $(67,68)$ reported results showing that the ultraviolet band of the spectrum was most attractive. The attractive range was between 3200A and 3987A. Attraction was increased when traps were placed over corn attractive for oviposition. Taylor \& Deay (142) confirmed the ultraviolet range of maximum attraction. They obtained a substantial reduction of first-generation borer infestation in the area of an electrocutor light trap in early planted sweet corn, but heavy oviposition and infestation occurred in a secondgeneration test. 


\section{IONIZING RADIATION}

The use of ionizing radiation to induce sterility in insects, which has occupied the attention of entomologists in recent years, was investigated by Walker (151) as a possible means of managing corn borer populations. He learned that exposure of one-day-old male moths to $32,000 \mathrm{r}$ of $\mathrm{x}$-rays resulted in a 1 per cent egg hatch when these males were mated to untreated females. The survival of the irradiated compared favorably with untreated males under laboratory conditions. This exploratory experiment indicated that this method of control was worthy of additional investigation.

Research on the biology of this insect and investigations of biological control factors, such as development of resistant varieties, ionizing radiation, chemically induced sterility, and sex attractants, may lead to the eventual management of this pest and the complete elimination of chemical control methods. Although the research on this insect is extensive and detailed, much remains to be accomplished.

\section{LITERATURE CITED}

1. Arbuthnot, K. D. Strains of the Euopean corn borer in the United States. U. S. Dept. Agr. Tech. Bull. No. 869, 20 pp. (1944)

2. Arbuthnot, K. D. Temperature and precipitation in relation to the number of generations of European corn borer in the: United States. U. S. Dept. Agr. Tech. Bull. No. 987, 22 pp. (1949)

3. Arbuthnot, K. D., and Wright, J. M. Parasites of the European corn borer in Illinois. Trans. Illinois State Acad. Sci., 44, 222-34 (1951)

4. Babcock, K. W. The European corn borer, Pyrausta nubilalis Hübn. II. A discussion of its seasonal history in relation to various climates. Ecology, 8, 177-9.4 (1927)

5. Baker, W. A., Bradley, W. G., and Clark, C. A. Biological control of the European corn borer in the United States. U. S. Dept. Agr. Tech. Bull. No. 983, 185 pp. (1949)

6. Baker, W. A., and Questel, D. D. Investigations of insecticides for control of the European corn borer at Toledo, Ohio. 1937-38. J. Econ. Entomol., 32, 526-30 (1939)

7. Bancroft, T. A., and Brindley, T. A. Methods for estimation of size of corn borer populations. Proc. Intern. Cong. Entomol., 10th, Montreal, 1956, 2, 1003-14 (1958)

8. Barber, G. W. The efficiency of birds in destroying overwintering larvae of the European corn borer in New England. Psyche, 32, $30-46$ (1925)

9. Barber, G. W. Some factors responsible for the decrease of the European corn borer in New England during 1923 and 1924. Ecology, 7, 143-62 (1926)

10. Barlett, K. A., and Lefebvre, C. L. Field experiments with Beauveria bassiana (Bals) Vuill., a fungus attacking the European corn borer. J. Econ. Entomol., 27, 1147-57 (1934)

11. Bartley, H. N., and Scott, L. B. Preliminary report upon the infestation and general status of the European corn borer in western New York. U. S. Dept. Agr. Circ. No. 197, 21 pp. (1931)

12. Batchelder, C. H. European corn borer location on the corn plant as related to insecticidal control. U. S. Dept. Agr. Tech. Bull. No. 976, 20 pp. (1949)

13. Batchelder, C. H., Questel, D. D., and Turner, O. European corn borer investigations. Experiments with insecticides on early sweet corn. Conn. Agr. Expt. Sta., New Haven, Bull. No. 395, 273-85 (1937)

14. Beall, G. The fit and significance of contagious distributions when applied to observations on larval insects. Ecology, 21, 460-74 (1940)

15. Beard, R. L. The significance of 
growth stages of sweet corn as related to infestation by the European corn borer. Conn. Agr. Expt. Sta., New Haven, Bull. No. 471, 173-99 (1943)

16. Beck, E: W. Status of the European

I corn borer in 1950. U. S. Dept. Agr. Insect Pest Survey, Spec. Suppl. 1, 20 pp. (1951)

17. Beck, S. D. Nutrition of the European corn borer (Pyrausta nubilalis Hbn.). IV. Feeding reactions of first instar larvae. Ann. Entomol. Soc. Am., 49, 388-405, 510 (1956)

18. Beck, S. D. The European corn borer, Pyrausta nubilalis (Hübner), and its principal host plant -IV. Larval saccharotropism and host plant resistance. Ann. Ento. mol. Soc. Am., 50, 247-50 (1957)

19. Beck, S. D., and Apple, J. W. Effects of temperature and photoperiod on voltinism of geographical populations of the European corn borer, Pyrausta nubilalis. J. Econ. Entomol., 54, 550-58 (1961)

20. Beck, S. D., and Hanec, W. Effect of amino acids on feeding behaviour of the European corn borer, $P \boldsymbol{y}$ rausta nubilalis (Hübn.). J. Insect Physiol., 2, 85-96 (1958)

21. Beck, S. D., and Hanec, W. Diapause in the European corn borer, Pyrausta nubilalis (Hübn.). J. Insect Physiol., 4, 304-18 (1960)

22. Beck, S. D., and Lilly, J. H. Report on European corn borer resistance investigations. Iowa State J. Sci., 23, 249-59 (1949)

23. Beck, S. D., Lilly, J. H., and Stauffer, J. F. Nutrition of the European corn borer, Pyrausta nubilalis (Hbn.). Ann. Entomol. Soc. Am., 42, 483-96 (1949)

24. Beck, S. D., and Smissman, E. The European corn borer, Pyrausta nubilalis Hübner), and its principal host plant-VIII. Laboratory evaluation of host plant resistance to larval growth and survival. Ann. Entomol. Soc. Am., 53, 75562 (1960)

25. Beck, S. D., and Smissman, E. The European corn borer, Pyrausta nubilalis (Hübner), and its principal host plant-IX. Biological activity of chemical analogs of corn resistance factor A (6-methoxybenzoxazolinone). Ann. Entomol. Soc. Am., 54, 53-59 (1961)

26. Beck, S. D., and Stauffer, J. F. An aseptic method for rearing Euro- pean corn borer larvae. J. Econ. Entomol., 43, 4-6 (1950)

27. Bell, M. E. Histology of the maize plant in relation to susceptibility to the European corn borer. Iowa State Coll. J. Sci., 31, 9-17 (1956)

28. Bigger, J. H., Decker, G. C., Wright, J. M., and Petty, H. B. Insecticides to control the European corn borer on field corn. J. Econ. Entomol., 40, 401-7 (1947)

29. Bigger, J. H., and Petty, H. B. Reduction of corn borer numbers from October to June, a ten-year study. Illinois Univ. Agr. Expt. Sta. Bull. No. 566, 15 pp. (1953)

30. Bird, R. D., and Stewart, W. W. A. The European corn borer in Manitoba and Saskatchewan. The Prairie Garden, 145-46 (April 30, 1959)

31. Blickenstaff, C. C., Arbuthnot, K. D., and Harris, H. M. Parasites of the European corn borer in Iowa. Iowa State Coll. J. Sci., 27, 335-79 (1952)

32. Bottger, G. T. Preliminary studies of the nutritive requirements of the European corn borer. J. Agr. Research, 60, 249-57 (1940)

33. Bottger, G. T. Development of synthetic food media for use in nutrition studies of the European corn borer. J. Agr. Research, 65, 493500 (1942)

34. Bottger, G. T. Sugars and protein in the corn plant as related to nutrition of the European corn borer. J. Econ. Entomol., 44, 40-44 (1951)

35. Bottger, G. T., and Kent, V. F. Seasonal history studies on the European corn borer in Michigan. $J$. Econ. Entomol., 24, 372-79 (1931)

36. Buligan, C. T. The corn borer, $P y$ rausta nubilalis Hübn. Philippine Agriculturist, 17, 397-450 (1929)

37. Burditt, A. K., Jr., and Holdaway, F. G. An evaluation of resistance of corn leaf tissue to feeding by European corn borer larvae. $J$. Econ. Entomol., 52, 1171-80 (1959)

38. Caffrey, D. J., and Worthley, L. H. A progress report on the investigations of the European corn borer. U. S. Dept. Agr. Bull. No. 1476, 155 pp. (1927)

39. Caffrey, D. J., and Worthley, L. H. The European corn borer: its present status and methods of control. 
U. S. Dept. Agr. Farmers Bull. No. 1548, 47 pp. (1927)

40. Cartwright, W. B. Observations on the European corn borer and its major parasites in the Orient. U. S. Dept. Agr. Circ. No. 289, 13 pp. (1933)

41. Chiang, H. C., and Hodson, A. C. Stalk breakage caused by the European corn borer and its effect on the harvesting of field corn. $J$. Econ. Entomol., 43, 415-22 (1950)

42. Chiang, H. C., and Holdaway, F. G. Evaluation of the intensity of predation of the European corn borer. Proc. Entomol. Soc. Am., N. Central Br., 10, 63-65 (1955)

43. Chiang, H. C., and Holdaway, F. G. Relative effectiveness of resistance of field corn to the European corn borer, Pyrausta nubilalis, in crop protection and in population control. J. Econ. Entomol., 53, 91824 (1960)

44. Chiang, H. C., Holdaway, F. G., Brindley, T. A., and Neiswander, C. R. European corn borer populations in relation to the estimation of crop loss. J. Econ. Entomol., 53, 517-22 (1960)

45. Chiang, H. C., Jarvis, J. L., Burkhardt, C. C., Fairchild, M. L., Weekman, G. T., and Triplehorn, C. A. Populations of European corn borer, Ostrinia nubilalis (Hbn.) in field corn, Zea mays (L.). Missouri Univ. Agr. Expt. Sta., Res. Bull. No. 776, 95 pp. (1961)

46. Christensen, J. J., and Schneider, C. L. European corn borer (Pyrausta nubilalis $\mathrm{Hbn}$.) in relation to shank, stalk, and ear rots of corn. Phytopathology, 40, 284-91 (1950)

47. Clark, C. A. The European corn borer and its controlling factors in the Orient. U. S. Dept. Agr. Tech. Bull., No. 455, 38 pp. (1934)

48. Conrad, M. S. The spotted lady beetle, Coleomegilla maculata (DeGeer), as a predator of European corn borer eggs. J. Econ. Entomol., 52, 843-47 (1959)

49. Cory, E. N., McConnel, H. S., Arbuthnot, K. D., and Jones, D. W. Parasites of the European corn borer in Maryland. Maryland Univ. Agr. Expt. Sta. Bull., No. $A 72,13$ pp. (1952)

50. Cox, H. C., and Brindley, T. A. Time of insecticide applications in European corn borer control. $J$.
Econ. Entomol., 51, 133-37 (1958)

51. Cox, H. C., Brindley, T. A., Lovely, W. G., and Fahey, J. E. Granulated insecticides for European corn borer control. J. Econ. Entomol., 49, 113-19 (1956)

52. Crawford, H. G., and Spencer, G. J. The European corn borer (Pyrausta nubilalis Hübn.): Life history in Ontario. Ann. Rep. Entomol. Soc. Ontario, 52, 22-26 (1922)

53. Decker, G. C. The biology of the stalk borer, Papaipema nebris (Gn.). Iowa Agr. Expt. Sta. Res. Bull., No. 143, 291-351 (1931)

54. Decker, G. C., Apple, J. W., Wright, J. M., and Petty, H. B. European corn borer control on canning corn. J. Econ. Entomol., 40, 395400 (1947)

55. Dicke, F. F. Studies on the host plants of the European corn borer, Pyrausta nubilalis Hübner, in southeastern Michigan. J. Econ. Entomol., 25, 868-78 (1932)

56. Dicke, F. F. Response of corn strains to European corn borer infestation. Proc. Entomol. Soc. Am., N. Central Br., 5, 47-49 (1950)

57. Dicke, F. F. Breeding for resistance to European corn borer. Proc. Ann. Hybrid Corn Industry Res. Conf., 9, 44-53 (1954)

58. Dicke, F. F., and Guthrie, W. D. Advances in European corn borer resistance research. Proc. Entomol. Soc. Am., N. Central Br., 10, 1213 (1935)

59. Dicke, F. F., Leuck, D. B., and Penny, L. H. The status of varietal resistance to second brood infestation of the European corn borer. Proc. Entomol. Soc. Am., N. Central Br., 13, 54-55 (1958)

60. Dicke, F. F., and Penny, L. H. European corn borer resistance and its source in new experimental field corn hybrids. Proc. Entomol. Soc. Am., N. Central Br., 11, 6768 (1956)

61. Eden, W. G. Research on European corn borer in Alabama. Georgia Entomol. Soc., 5, 1-3 (1959)

62. Everett, T. R., Chiang, H. C., and Hibbs, E. T. Some factors influencing populations of European corn borer [Pyrausta nubilalis (Hbn.)] in the north central states. Minnesota Univ. Aor. Expt. Sta. Tech. Bull. No. 229, 63 pp. (1958)

63. Everly, R. T. Studies on the attractiveness of dent corn to moths of 
the European corn borer. Proc. Indiana Acad. Sci. 1946, 56, 145 (1947)

64. Everly, R. T. Influence of height and stage of development of dent corn on oviposition by European corn borer moths. Ann. Entomol. Soc. Am., 52, 272-79 (1959)

65. Fahey, J. E., Brindley, T. A., Rusk, H. H. Three years' study of DDT residues on corn plants treated for European corn borer control. Iowa State Coll. J. Sci., 28, 20959 (1953)

66. Ficht, G. A. The European corn borer in Indiana. Purdue Univ. Agr. Expt. Sta. Bull. No. 406, 1-24 (1936)

67. Ficht, G. A., and Heinton, T. E. Studies on the flight of European corn borer moths to light trapsA progress report. J. Econ. Entomol., 32, 599-604 (1939)

68. Ficht, G. A., and Heinton, T. E. Flight of corn borer moths to light traps. J. Econ. Entomol., 34, 599604 (1941)

69. Fleming, A. A., Singh, R., Hayes, H. K., and Pinnell, E. L. Inheritance in maize of reaction to European corn borer and its relationship to certain agronomic characters. Minnesota Univ. Agr. Expt. Sta. Tech. Bull. No. 226, 32 pp. (1958)

70. Gibson, A., and McLaine, L. S. The European corn borer. Can. Dept. Agr. Prot. Leaflet No. 13, 3 pp. (1920)

71. Guthrie, W. D., Dicke, F. F., and Neiswander, C. R. Leaf and sheath feeding resistance to the European corn borer in eight inbred lines of dent corn. Ohio. Agr. Expt. Sta. Res. Bull. No. 860, 38 pp. (1960)

72. Guthrie, W. D., and Stringfield, G. $H$. The recovery of genes controllong corn borer resistance in a backcrossing program. J. Econ. Entomol., 54, 267-70 (1961)

73. Guthrie, W. D., and Stringfield, G. $\mathrm{H}$. Use of test crosses in breeding for resistance to the European corn borer. J. Econ. Entomol., 54, 784-87 (1961)

74. Guthrie, W. D., and Walter, E. V. Corn earworm and European corn borer resistance in sweet corn inbred lines. J. Econ. Entomol., 54, 1248-50 (1961)

75. Hervey, G. E. R., and Palm, C. E.
A preliminary report on the response of the European corn borer to light. J. Econ. Entomol., 28, 670-75 (1935)

76. Hibbs, E. T., Guthrie, W. D., and Neiswander, C. R. The yield performance of a resistant and a susceptible field corn hybrid under different intensities of European corn borer infestation. Ohio Agr. Expt. Sta. Res. Bull. No. 818, 27 pp. (1958)

77. Hodgson, B. E. The host plants of the European corn borer in New England. U. S. Dept. Agr. Tech. Bull. No. 77, 64 pp. (1928)

78. Horber, E. Versuche zur Verhinder. ung der vom Maikãferengerling (Melolontha vulgaris F.), von der Fritfliege (Oscinella frit L.) und vom Maizünsler Pyrausta nubilalis (Hbn.) verursachten Schäden mittels resistenter Sorten. Landwirtsch. Jahrb. Schweiz (75 Jahr) N.F., 19, 635-69 (1961)

79. Huber, L. L. Mortality of first instar larvae of the European corn borer. Ohio Agr. Expt. Sta. Bull. No. 561, 44 pp. (1936)

80. Huber, L. L., Neiswander, C. R., and Salter, R. M. The European corn borer and its environment. Ohio Agr. Expt. Sta. Bull. No. 429, 196 pp. (1928)

81. Huber, L. L., and Stringfield, G. H. Aphid infestation of strains of corn as an index of their susceptibility to corn borer attack. J. Agr. Research, 64, 283-91 (1942)

82. Hudon, M. Some aspects of seasonal development of the European corn borer, Ostrinia nubilalis (Hübn) in southwestern Quebec. Quebec Soc. Protect. Plants, 41, 121-28 (1959)

83. Hudon, M. Field experiments with Bacillus thuringiensis and chemical insecticides for the control of the European corn borer, Ostrinia nubilalis, on sweet corn in southwestern Quebec. J. Econ. Entomol., 55, 115-17 (1962)

84. Ibrahim, M. A. Association tests between chromosomal interchanges in maize and resistance to the European corn borer. Agron. J., 46, 293-98 (1954)

85. Iowa State University. The European corn borer and its control in the north central states. N. Central Reg. Publ. 22 (rev.), Ext. Pamphlet No. 176, 8 pp. (1961) 
86. Jarvis, J. L. Interrelation of factors influencing populations of the European corn borer in Boone County, Iowa. (Unpublished doctoral thesis, Library, Iowa State Univ., Ames, Iowa, 1961)

87. Jones, D. W., and Caffrey, D. J. Status of imported parasites of the European corn borer. U. S. Dept. Agr. Circ. No. 14, 7 pp. (1927)

88. Jones, D. W., Walker, H. G., and Anderson, L. D. The European corn borer on the eastern shore of Virginia. Virginia Truck Expt. Sta. Bull. No. 102, 1621-48 (1939)

89. Karpova, A. I. Development and food lines of Pyrausta nubilalis $\mathrm{Hb}$. in new regions of maize cultivation. Entomol. Obozrenie, 38, 724-33 (1959)*

90. Kotlan, A. A double parasitic infection of a larva of Pyrausta nubilalis Hb. Intern. Corn Borer Invest. Sci. Repts., 1, 174-78 (1928)

91. Kwolek, W. F., and Brindley, T. A. The effects of the European corn borer, Pyrausta nubilalis (Hbn.) on corn yield. Iozja State Coll. J. Sci., 33, 293-323 (1959)

92. Loomis, R. S., Beck, S. D., and Stauffer, J. F. The European corn borer (Pyrausta nubilalis (Hbn.)) and its principal host plant. V. A chemical study of host plant resistance. Plant Physiol., 32, 37985 (1957)

93. Marion, H. Complement a la classification et nomenclature des Pyrausidae D'Europe. L'Entomologiste, 13, 130 (1957)

94. Marston, A. R. Breeding European corn borer resistant corn. J. Am. Soc. Agron., 23, 960-64 (1931)

95. Marston, A. R., and Dibble, C. B. Investigations of corn borer control at Monroe, Michigan. Mich. State Univ. Agr. Expt. Sta. Spec. Bull. No. 204, 47 pp. (1930)

96. Marston, A. R., and Mahoney, C. H. Progress report on breeding of sweet corn for corn borer resistance. Proc. Am. Soc. Hort. Sci., 29, 472-76 (1932)

97. McConnell, E., and Cutcomp, L. K. Studies with Bacillus thuringiensis in relation to the European corn borer. J. Econ. Entomol., 47, 1074-82 (1954)

98. McCoy, C. E., and Brindley, T. A. Biology of the four-spotted fungus beetle Glischrochilus q. quadrisignatus and its effect: on Euro- pean corn borer populations. $J$. Econ. Entomol., 54, 713-17 (1961)

99. McGuire, J. U., Brindley, T. A., and Bancroft, T. A. The distribution of European corn borer larvae, Pyrausta nubilalis ( $\mathrm{Hbn}$.$) , in$ field corn. Biometrics, 13, 65-78 (1957)

100. Metalnikov, S., and Chorine, V. Experiments on the use of bacteria to destroy the corn borer. Intern. Corn Borer Invest. Sci. Repts., 2, 54-59 (1929)

101. Meyers, M. T., Huber, L. L., Neiswander, C. R., Richey, F. D., and Stringfield, G. H. Experiments on breeding corn resistant to the European corn borer. U. S. Dept. Agr. Tech. Bull. No. 583, 29 pp. (1937)

102. Meyers, M. T., and Patch, L. H. A statistical study of sampling in field surveys of the fall population of the European corn borer. J. Agr. Research, 55, 849-71 (1937)

103. Mutchmore, J. A., and Beckel, W. E. Some factors affecting diapause in the European corn borer, Ostrinia nubilalis (Hbn.) Can. J. Zool., 37, 161-68 (1959)

104. Nagy, B. Lesions and forms of injuries on hemp caused by the European corn borer, Pyrausta nubilalis Hbn. Kiserl. Kozlem, 52[A], 48-68 (1959)

105. Paillot, A. Importance relative des facteurs divers contributant a limiter l'extension de la pyrale da mais dans l'est de la France. Compt. rend., 182, 149-51 (1928)

106. Painter, R. H. The economic value and biologic significance of plant resistance to insect attack. $J$. Econ. Entomol., 34, 358-6\% (1941)

107. Painter, R. H., and Weibel, D. E European corn borer damage tc grain sorghums. J. Econ. Entomol. 44, 796-98 (1951)

108. Patch, L. H. Resistance of a single cross hybrid strain of field corn tc European corn borer. J. Econ Entomol., 30, 271-78 (1937)

109. Patch, L. H. Height of corn as a factor in egg laying by the Euro. pean corn borer moth in the one. generation area. J. Agr. Research 64, 503-15 (1942)

110. Patch, L. H. Survival, weight anc location of European corn borer: feeding on resistant and susceptible field corn. J. Agr. Research, 66 7-19 (1943) 
111. Patch, L. H. Manual infestation of dent corn to study resistance to European corn borer. J. Econ. Entomol., 40, 667-71 (1947)

112. Patch, L. H., Bottger, G. T., and App, B. A. Comparative resistance to the European corn borer of two hybrid strains of field corn at Toledo, Ohio. J. Econ. Entomol., 31, 337-40 (1938)

113. Patch, L. H., Deay, H. O., and Snelling, R. O. Stalk breakage of dent corn infested with the August generation of the European corn borer. J. Econ. Entomol., 44, 53439 (1951)

114. Patch, L. H., and Everly, R. T. Resistance of dent corn inbred lines to survival of first-generation European corn borer larvae. U. S. Dept. Agr. Tech. Bull. No. 893, 10 pp. (1945)

115. Patch, L. H., and Everly, R. T. Contribution of inbred lines to the resistance of hybrid dent corn to larvae of the early summer generation of the European corn borer. J. Agr. Research, 76, 257-63 (1948)

116. Patch, L. H., Still, G. W., App, B. A., and Crooks, C. A. Comparative injury by the European corn borer to open-pollinated and hybrid field corn. J. Agr. Research, 63, 35568 (1941)

117. Patch, L. H., Still, G. W., Schlosberg, M., and Bottger, G. T. Factors determining the reduction in yield of field corn by the European corn borer. J. Agr. Research, 65, 473-82 (1942)

118. Penny, L. H., and Dicke, F. F. Inheritance of resistance in corn to leaf feeding of the European corn borer. Agron. J., 48, 200-3 (1956)

119. Penny, L. H., and Dicke, F. F. A single gene-pair controlling segregation of European corn borer resistance. Agron. J., 49, 193-96 (1957)

120. Penny, L. H., and Dicke, F. F. European corn borer damage in resistant and susceptible dent corn hybrids. Agron. J., 51, 323-26 (1959)

121. Pepper, B. B., and Carruth, L. A. A new plant insecticide for control of the European corn borer. J. Econ. Entomol., 38, 59-66 (1945)

122. Pepper, B. B., and Haeusler, C. M. Control of the European corn borer and ear smut on sweet corn with dusts and sprays. New Jersey
Agr. Expt, Sta. Circ., No. 486, 14 pp. (1944)

123. Pesho, G. R. Female mating patterns and spermatophore counts in the European corn borer, Pyrausta nubilalis (Hbn.). Proc. Entomol. Soc. Am. N. Central Branch, 16, 43 (1961)

124. Peters, D. C., Burditt, A. K., Jr., and Fairchild, M. L. The biology and control of the European corn borer in Missouri. Missouri Univ. Research Bull. No. 257, 26 pp. (1961)

125. Poos, F. W. Biology of the European corn borer and two closely related species in northern Ohio. Ohio J. Sci., 27, 47-94 (1927)

126. Questel, D. D. DDT as a substitute for Derris against the European corn borer. J. Econ. Entomol., 37, 149-50 (1944)

127. Raun, E. S., Elimination of microsporidiosis in laboratory reared European corn borers by the use of heat. J. Insect Pathol., 3, 44648 (1961)

128. Raun, E. S., York, G. T., and Brooks, D. L. Determination of Perezia pyraustae infection in larvae of the European corn borer. J. Insect Pathol., 2, 254-58 (1960)

129. Reed, C. O., Gray, R. B., Worthley, L. H., and Caffrey, D. J. Fighting the corn borer with machinery in the two-generation area. U. S. Dept. Agr. Circ. No. 132, 49 pp. (1930)

130. Revelo, M. A. Field experiments with the fungus Beauveria bassiana (Bals) Vuill. for control of the European corn borer. (Master's thesis, Iowa State Univ., Ames, Iowa, 1959)

131. Ritcher, P. O. European corn borer in Kentucky. Ky. Agr. Expt. Sta. Bull. No. 502, 23 pp. (1947)

132. Rolston, L. H., Neiswander, C. R., Arbuthnot, K. D., and York, G. T. Parasites of the European corn borer in Ohio. Ohio Agr. Expt. Sta. Res. Bull. No. 819, 35 pp. (1958)

133. Roubaud, E. Biological researches on Pyrausta nubilalis $\mathrm{Hb}$. Intern. Corn Borer Invest. Sci. Repts., 1, 1-40 (1928)

134. Schlosberg, M., and Baker, W. A. Tests of sweet corn lines for resistance to European corn borer larvae. J. Agr. Research, 77, 13756 (1958)

135. Smissman, E. E., Lapidus, J. B., and Beck, S. D. Isolation and syn- 
thesis of an insect resistant factor from corn plants. J. A Am. Chem. Soc., 79, 4697-98 (1957)

136. Smith, C. A. S. The first records of European corn borer in western Canada. Ann. Rept. Entomol. Soc. Ontario, 80, 18-19 (1949)

137. Smith, H. E. Broomcorn the probable host in which Pyrausta nubilalis Hübn. reached America. $J$. Econ. Entomol., 13, 425-30 (1920)

138. Spencer, G. J., and Crawford, H. G. The European corn borer in Ontario. Ontario Dept. Agr. Bull. No. 295, 11 pp. (1923)

139. Steinhaus, E. A. Principles of insect pathology (McGraw-Hill Book Co., Inc., New York, 757 pp., 1949)

140. Stirrett, G. M. A field study of the flight, oviposition and establishment periods in the cycle of the European corn borer, Pyrausta nubilalis Hbn., and the physical factors affecting them. Sci. Agr., 18, 355-69, 462 (1938)

141. Takeuchi, S. Comparative studies on the corn borer attackins corn and bean. Hokkaido Noji Shikensho Hokoku, 74, 80-86 (19.59)

142. Taylor, J. G., and Deay, H. O. Electric lamps and traps in corn borer control. Agr. Eng., 31, 503-5, 532 (1950)

143. Thomas, W. L., Dickie, F. F., and Eldredge, J. C. Resistance in popcorn to European corn borer $(P y$ rausta nubilalis) leaf feeding. Agron. J., 52, 299 (1960)

144. Thompson, W. R., and Parker, H. L. The European corn borer and its controlling factors in Europe. U. S. Dept. Agr. Tech. Bull., No. 59, 62 pp. (1928)

145. Turner, N., and Beard, R. L. Effect of stages of growth of field corn inbreds on oviposition and survival of the European corn borer. J. Econ. Entomol., 43, 17-22 (1950)

146. Vance, A. M. Studies on the prevalence of the European corn borer in the east north central states. U. S. Dept. Agr. Circ. No. 649, 23 pp. (1942)

147. Viado, G. B., Banaag, A. F., and Luis, R. A. Some organic insecti- cides in the control of the corn earworm and the corn borer on green corn. Philippine Agr., 41, 402-11 (1957)

148. Vinal, S. C. The European corn borer, Pyrausta nubilalis Hübner, a recently established pest in Massachusetts. Mass. Agr. Expt. Sta. Bull. No. 178, 147-52 (1917)

149. Vinal, S. C. and Caffrey, D. J. The European corn borer and its control. Mass. Expt. Sta. Bull. No. 189, 71 pp. (1919)

150. Virtanen, A. I. Some aspects of factors in the maize plant with toxic effects on insect larvae. Suomen Kemistilehti, [B] 34, 29-31 (1961)

151. Walker, J. R. Evaluation of control of European corn borer, Ostrinia nubilalis (Hübner), by $\mathrm{X}$ ray induced sterility. (Doctoral thesis, Iowa State University, Ames, Iowa 1962)

152. Wallengren, $H$., and Johansson, $R$. On the infection of Pyrausta nubilalis $\mathrm{Hb}$. by Metarrhizium anisopliae (Metsch.) Sor. Intern. Corn Borer Invest. Sci. Repts., 2, 131-45 (1929)

153. Worthley, L. H., and Caffrey, D. J. Scouting, quarantine and control for the European corn borer 19171926. U. S. Dept. Agr. Tech. Bull. No. 53, 143 pp. (1927)

154. Wressell, H. B. The European corn borer, Pyrausta nubilalis (Hbn.), in Canada: A review. Ann. Rept. Entomol. Soc. Ontario, 84, 45-48 (1953)

155. York, G. T. Field tests with the fungus Beauveria sp. for control of the European corn borer. Iowa State Coll. J. Sci., 33, 123-29 (1958)

156. York, G. T., Schaffner, J. C., and Brindley, T. A. Parasites of the European corn borer found infesting the stalk borer. J. Econ. Entomol., 48, 565-71 (1955)

157. Zimmack, H. L., Arbuthnot, K. D., and Brindley, T. A. Distribution of the European corn borer parasite Perezia pyraustae, and its effect on the host. J. Econ. Entomol., 47, 641-45 (1954)

* English translations will be announced in Technical Translations, issued by the Office of Technical Services, U. S. Department of Commerce, and will be made available by the Photoduplication Service, Library of Congress, and by the SLA Translation Center at the John Crerar Library, Chicago, Illinois. 